\title{
EFFECT OF AUTOLIZED YEAST AND PEPTONE ON GROWTH OF EXCISED CORN ROOT TIPS IN THE DARK ${ }^{x}$
}

\author{
William J. Rов BINS \\ (WITH EIGHT FIGURES)
}

In a previous paper ${ }^{2}$ the writer described a simple method by which the excised root tips and stem tips of higher plants can be cultivated under sterile conditions, and some experiments in which this method was used. These experiments showed that the excised root tips of corn would make considerable growth in the dark in a sterile nutrient solution containing mineral salts and glucose, and but little when no carbohydrate was present. It was found, however, that the amount of growth which a corn root tip would make under these conditions was limited. If the original root tips were grown for ten days or two weeks in the dark in the nutrient solutions containing glucose, and then their tips cut off and transferred to fresh nutrient solutions, the amount of growth and production of secondary roots was decidedly less in the second period than in the first, and ceased entirely in the third. The following causes for this cessation of growth were suggested: (I) an unbalanced condition of the nutrient solution, (2) a deficiency of oxygen, (3) incompleteness of the nutrient solution, that is, the lack of some constituent necessary for continued growth. A consideration of the conditions of the experiments and the results obtained suggested that the third possibility should be used as a working hypothesis. This assumption does not eliminate the possibility that the cessation of growth is due to one or both of the other two factors, or that it is due to some factor not considered. It is merely used as the basis for further experimentation.

${ }^{2}$ Published with permission of the Director of the Agricultural Experiment Station, University of Missouri. The writer acknowledges the kindness of Dr. J. K. WrLson in supplying the Longfellow Flint corn used in this investigation, and the assistance of Dr. W. E. MANEVAL in making the transfers involved in experiments 12 and 14.

${ }^{2}$ Robbins, W. J., Cultivation of excised root tips and stem tips under sterile conditions. Вот. GAZ. 73:376-390. 1922 . 


\section{Growth of roots attached and detached from grain}

That the seed supplies material different either in kind or in quantity from that present in the culture solution is evidenced by the following experiment, in which a comparison was made of the growth of roots attached to the grain and detached from the grain. In this experiment corn grains were sterilized by WiLson's method as before, and germinated on sterile agar in Petri dishes. After germination, and when the roots were about $3 \mathrm{~cm}$. long, some of the grains were placed in $50 \mathrm{cc}$. of sterile modified Pfeffer's solution plus 2 per cent glucose in $125 \mathrm{cc}$. Erlenmeyer flasks, and some of the root tips were cut off and transferred to the same kind of solution and culture flasks. All were placed in the dark at room temperature. At the end of twelve days the roots attached to the grains had gained $26.6 \mathrm{~cm}$., had produced 102 secondary roots on the average, and weighed per ten roots $0.5 \mathrm{I} 20 \mathrm{gm}$. Those detached from the grain had gained $12.4 \mathrm{~cm}$., had eighty-three secondary roots, and weighed per ten roots but $0 . \mathrm{II}_{3} 8 \mathrm{gm}$. (table I).

\section{TABLE I}

GROWTH IN DARK OF ROOTS ATTACHED TO GRAIN AND DETACHED FROM GRAIN, IN PfEFFER'S SOLUTION PLUS 2 PER CENT GLUCOSE

\begin{tabular}{|c|c|c|c|c|}
\hline Condition & $\begin{array}{l}\text { Average origi- } \\
\text { nal length } \\
\text { (cm.) }\end{array}$ & $\begin{array}{c}\text { Gain in } \\
\text { length } \mathrm{I}_{2} \text { days } \\
(\mathrm{cm} .)\end{array}$ & $\begin{array}{l}\text { Average no. } \\
\text { secondary } \\
\text { roots }\end{array}$ & $\begin{array}{l}\text { Dry weight } \\
\text { per ro roots } \\
\text { (gm.) }\end{array}$ \\
\hline $\begin{array}{l}\text { Attached to grain } \ldots \ldots \ldots \ldots \ldots \ldots \\
\text { Cut off } \ldots \ldots \ldots \ldots \ldots\end{array}$ & $\begin{array}{r}2.9 \\
1.7\end{array}$ & $\begin{array}{l}26.6 \\
\mathbf{1} 2.4\end{array}$ & $\begin{array}{r}102 \\
83\end{array}$ & $\begin{array}{l}0.5120 \\
0.1138\end{array}$ \\
\hline
\end{tabular}

In tubes of I per cent agar a similar difference in the growth of roots attached to the grain and detached from the grain was noted. In fig. I the growth of an excised root tip at the end of two weeks in modified Pfeffer's solution plus 2 per cent glucose containing I per cent agar, and the growth in the same period of time of a root which was left attached to the grain are shown. Comparing the latter root with the excised root, its greater length, greater size of secondary roots, and greater diameter of root tip are clearly evident.

\section{The effect of peptone and autolized yeast}

If we assume that the stoppage in growth of an excised corn root tip on continued transfers is because glucose, the mineral salts of 
Pfeffer's solution, oxygen, and water are insufficient for continued root growth, the natural place to look for the materials lacking is the grain or the plant. Extracts of the young embryos including both roots and tops, and of young seedlings a week or ten days old did not benefit the excised root tips. In fact, these extracts used in the proportion of the extract of one embryo or seedling to one root tip showed a slight injurious effect upon the growth of the root.

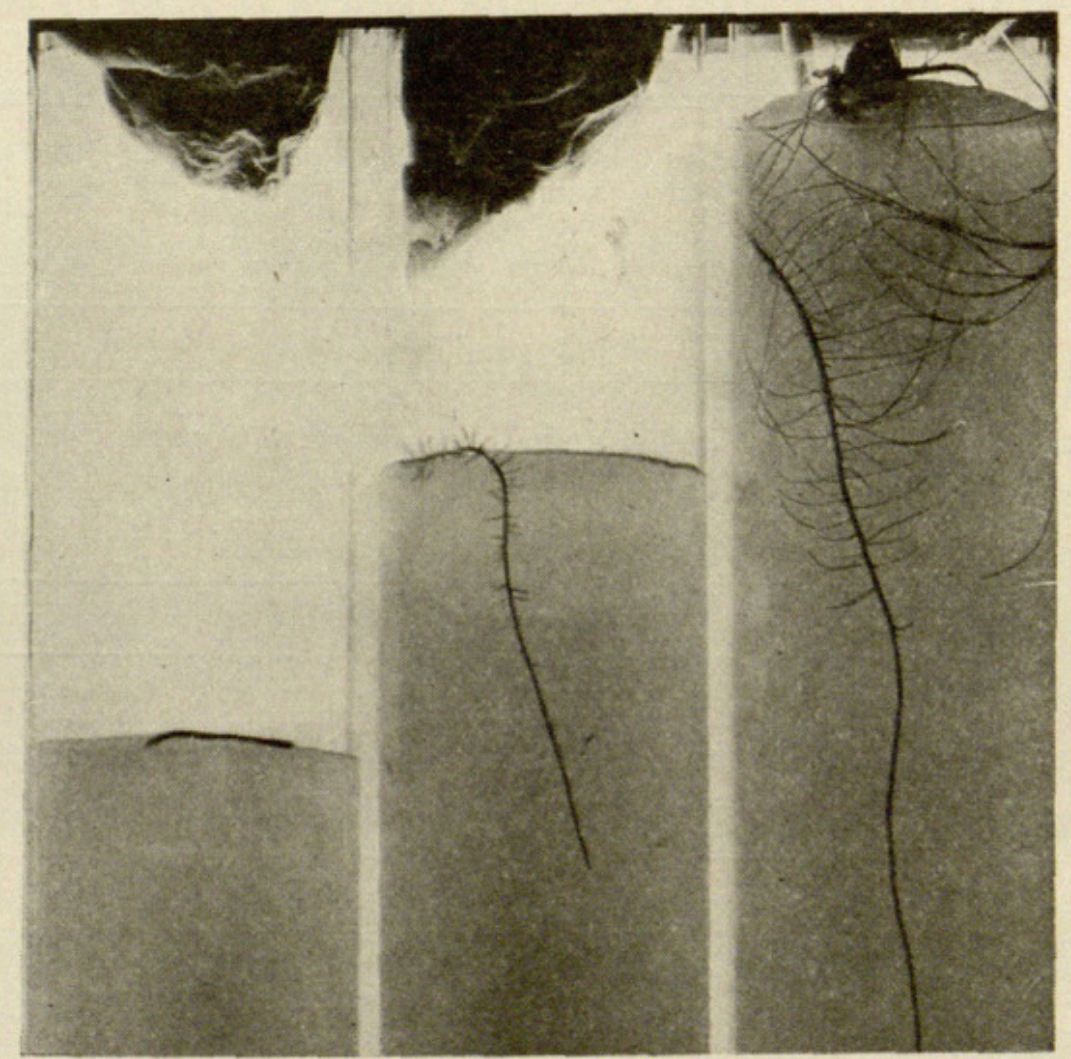

FIG. I.-Corn root tips originally about $2 \mathrm{~cm}$. long: (I) excised root tip in Pfeffer's solution plus I per cent agar; (2) excised root tip in Pfeffer's solution plus I per cent agar and 2 per cent glucose; (3) root tip of root attached to grain in Pfeffer's solution plus 2 per cent agar.

Neither did creatinine, gylcocoll, or asparagin used at the concentration of $100 \mathrm{ppm}, 79 \mathrm{ppm}$, and $50 \mathrm{ppm}$ respectively produce any better growth. The first two substances were slightly injurious, the last one no better than the check. Two experiments in which the $\mathrm{Ca}\left(\mathrm{NO}_{3}\right)_{2}$ and $\mathrm{KNO}_{3}$ of Pfeffer's solution were replaced by $\mathrm{CaCl}_{2}$ and $\mathrm{KCl}$, and in which the roots were carried through three periods of culture, showed that the lack of nitrate somewhat decreased the total amount of growth in length instead of increasing it, as generally occurs in water cultures lacking nitrogen when the 
root is attached to the grain. Peptone and autolized yeast, however, were found to be distinctly beneficial. These two substances were selected because they contained a variety of comparatively simple organic nitrogenous materials, and because they are known to be beneficial to the growth of lower plants, such as the bacteria or the yeasts.

TABLE II

EFFECT OF PEPTONE AND AUTOLIZED YEAST ON GROWTH IN DARK OF CORN ROOT TIPS CUT OFF AND TRANSFERRED

\begin{tabular}{|c|c|c|c|c|c|c|c|}
\hline $\begin{array}{l}\text { Addition to } \\
\text { PFEFFER's solution } \\
+2 \% \text { glucose }\end{array}$ & No. roots & $\begin{array}{l}\text { Average } \\
\text { original } \\
\text { length } \\
\text { (cm.) }\end{array}$ & $\begin{array}{l}\text { Average } \\
\text { gain in } \\
\text { length } \\
\text { (cm.) }\end{array}$ & $\begin{array}{l}\text { Average } \\
\text { no. side } \\
\text { roots }\end{array}$ & $\begin{array}{c}\text { Dry weight } \\
\text { per I0 } \\
\text { roots }(\mathrm{gm} .)\end{array}$ & Original $P_{n}$ & $\begin{array}{l}\text { Average } \\
\text { final } P_{\mathrm{H}}\end{array}$ \\
\hline \multirow{3}{*}{$\begin{array}{l}\text { None. . . . . . . } \\
\text { None.......... } \\
\text { None........ }\end{array}$} & \multicolumn{7}{|c|}{ x. June $2 \mathrm{I}$-July 4} \\
\hline & $\begin{array}{l}8 \\
8 \\
8\end{array}$ & $\begin{array}{l}\text { I. } 7 \\
\text { I. } 7 \\
\text { I. } 9\end{array}$ & $\begin{array}{l}\text { II. } 6 \\
12.7 \\
12.8\end{array}$ & $\begin{array}{l}68 \\
68 \\
63\end{array}$ & $\begin{array}{l}0.0487 \\
0.0560 \\
0.0485\end{array}$ & $\begin{array}{l}4 \cdot 5 \\
4 \cdot 5 \\
4 \cdot 5\end{array}$ & $\begin{array}{l}6.8 \\
6.5 \\
6.3\end{array}$ \\
\hline & \multicolumn{7}{|c|}{ 2. July 4-July 22} \\
\hline $\begin{array}{l}\text { None. .......... } \\
0.04 \% \text { peptone... } \\
0.02 \% \text { yeast.... }\end{array}$ & $\begin{array}{l}8 \\
8 \\
8\end{array}$ & $\begin{array}{l}\text { I. } 6 \\
\text { I. } 7 \\
\text { I. } 7\end{array}$ & $\begin{array}{l}2 \cdot 5 \\
4 \cdot 3 \\
2 \cdot 2\end{array}$ & $\begin{array}{r}8.0 \\
16.0 \\
10.0\end{array}$ & $\begin{array}{l}0.0030 \\
0.0283 \\
0.0371\end{array}$ & $\begin{array}{l}4 \cdot 5 \\
6 \cdot 5 \\
5 \cdot 2\end{array}$ & $\begin{array}{l}5.04 \\
6.5 \\
5.3\end{array}$ \\
\hline \multirow{3}{*}{$\begin{array}{l}\text { None } . . . . . . . \\
0.04 \% \text { peptone... } \\
0.02 \% \text { yeast..... }\end{array}$} & \multicolumn{7}{|c|}{ 3. July $22-$ August 20} \\
\hline & $\begin{array}{l}8 \\
4 \\
2\end{array}$ & $\begin{array}{l}\text { I. } 5 \\
\text { I. } 8 \\
\text { I. } 5\end{array}$ & $\begin{array}{l}0.05 \\
4.1 \\
5.2\end{array}$ & $\begin{array}{l}0 \\
\text { II. } \\
21.0\end{array}$ & $\begin{array}{l}\cdots \cdots \\
\cdots \cdots \\
\cdots \cdots\end{array}$ & $\begin{array}{l}4 \cdot 5 \\
6.5 \\
5 \cdot 2\end{array}$ & $\begin{array}{l}4.6 \\
6.42 \\
5.45\end{array}$ \\
\hline & \multicolumn{7}{|c|}{ 4. August $20-N o v e m b e r ~ 12$} \\
\hline $\begin{array}{l}\text { None............ } \\
0.04 \% \text { peptone... } \\
0.02 \% \text { yeast.... }\end{array}$ & $\begin{array}{l}3 \\
\mathrm{I}\end{array}$ & $\begin{array}{l}2.0 \\
2.0\end{array}$ & $\begin{array}{l}\text { I. } 6 \\
3.5\end{array}$ & $\begin{array}{l}4.5 \\
4.0\end{array}$ & $\begin{array}{l}\cdots \\
\cdots\end{array}$ & $\cdots$ & . \\
\hline
\end{tabular}

The first experiment with peptone and autolized yeast was begun June 21, 1920, and completed November I 2 of the same year. The second experiment extended from December I3, 1920, to February 5, I92I. Both experiments demonstrated that excised corn roots whose tips were severed and transferred about every two weeks would grow in the dark in sterile solutions containing peptone or autolized yeast, glucose, and the salts of Pfeffer's solution for four to six two-week periods, while without the peptone or autolized 
yeast growth stopped in the third two-week period. Autolized yeast appeared to be somewhat more favorable than peptone. The details of these two experiments are as follows.

Experiment 5.-In this experiment the method of culture was as previously described. Grains of Longfellow flint corn were sterilized by WiLson's hypochlorite method. The excised tips of the original primary roots were grown in the modified Pfeffer's solution plus 2

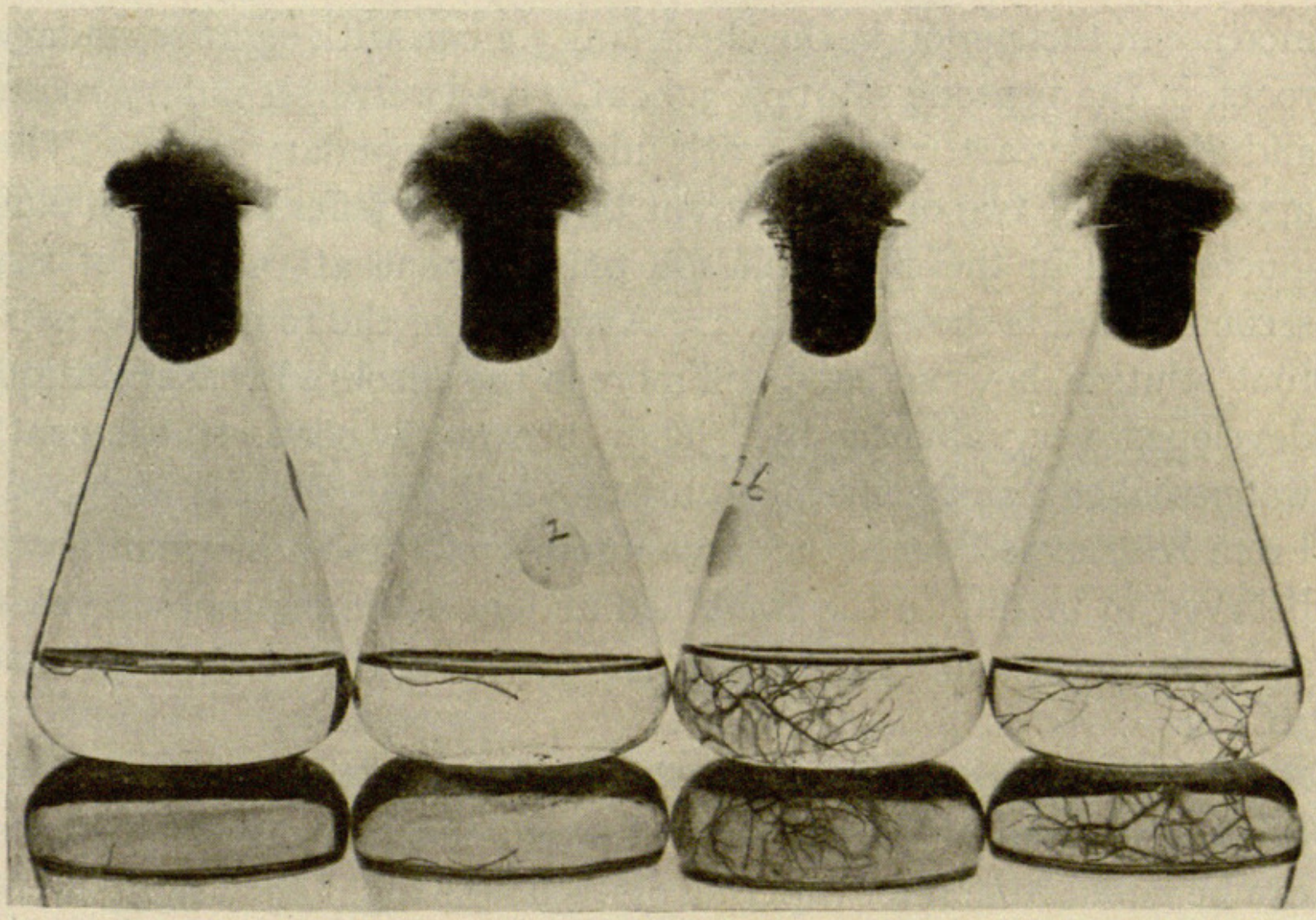

Fig. 2.-Effect of peptone at end of second period on growth of corn root tips in dark; two root tips on left in Pfeffer's solution plus 2 per cent glucose, two on right in same solution plus about $400 \mathrm{ppm}$ peptone.

per cent glucose. The root tips of these excised roots were cut off after eleven days and transferred to the same solution, to the same solution plus peptone, or to the same solution plus autolized yeast. Further transfers were made as indicated in table II. Erlenmeyer flasks of $125 \mathrm{cc}$. capacity containing $50 \mathrm{cc}$. of solution were used. One cc. of a sterile 2 per cent solution of Difco peptone was added to each flask containing peptone, and I cc. of a sterile I per cent autolized yeast suspension was added to each flask containing autolized yeast. This produced solutions containing approximately 
$400 \mathrm{ppm}$ of peptone and $200 \mathrm{ppm}$ of autolized yeast. Both the yeast and peptone were sterilized intermittently at $100^{\circ} \mathrm{C}$. The root tips were grown in the dark at room temperature.

The beneficial effect of the peptone and the autolized yeast began to be evident toward the end of the second period of growth. From the data in table II it can be noted that the root tips in the peptone solution show distinctly greater growth in length, production of secondary roots, and greater increase in dry weight. The maximum increase in this period in the check was $3.2 \mathrm{~cm}$. with eight secondary roots, in the peptone solution $3.6 \mathrm{~cm}$. with twelve secondary roots, and in the yeast $5.5 \mathrm{~cm}$. with nineteen secondary roots. The appearance of two of the best root tips in the Pfeffer's solution plus glucose and in the same solution plus peptone at the end of the second period is shown in fig. 2. A number of the roots in the peptone solution, however, and still more in the autolized yeast solution developed very abnormally. They became swollen, translucent, water-soaked, and extremely brittle, and growth was stopped. From later experiments the large number of these abnormalities is believed to be due to the combined action of the peptone or yeast and the comparatively high room temperature of July (about $30^{\circ} \mathrm{C}$.).

The dry weights of the root tips in the yeast and peptone solutions at the end of the second period were comparatively high, as can be noted from later experiments. These high dry weights were due to the large number of thickened and abnormal roots which developed in this period in the yeast and peptone solutions. Of the eight roots in the peptone only four were transferred, and of the eight roots in the yeast only two were transferred. These grew in the third period, however, while the check root tips did very little, as can be noted in table II. The maximum growth in the third period in the check was $0.3 \mathrm{~cm}$. with no secondary roots, in peptone $7.8 \mathrm{~cm}$. with twenty-nine secondary roots, in the yeast solution 9.4 $\mathrm{cm}$. with forty secondary roots. The tips of three of the four roots in the peptone solution were transferred and one of the two roots in yeast. These grew in the fourth period, the maximum in the peptone being $4.5 \mathrm{~cm}$. with no secondary roots, and in the yeast $3.5 \mathrm{~cm}$. with four secondary roots. The one root in the yeast solution was 
lost by contamination. The results of this experiment, so far as length increase is concerned, are presented graphically in fig. 3 .

Determinations of the $\mathrm{H}$-ion concentration of the solutions used in this experiment were made by GILLESPIE's ${ }^{3}$ method at the beginning and at the end of the first, second, and third periods. The modified Pfeffer's solution at the beginning of each period had a $\mathrm{P}_{\mathrm{H}}$ of $4 \cdot 5$. The addition of the quantity of peptone used made the solution more alkaline, raising the $\mathrm{P}_{\mathrm{H}}$ to 6.5 . The autolized yeast had a similar though less marked effect, raising the $P_{\text {H }}$ to 5.2. The growth

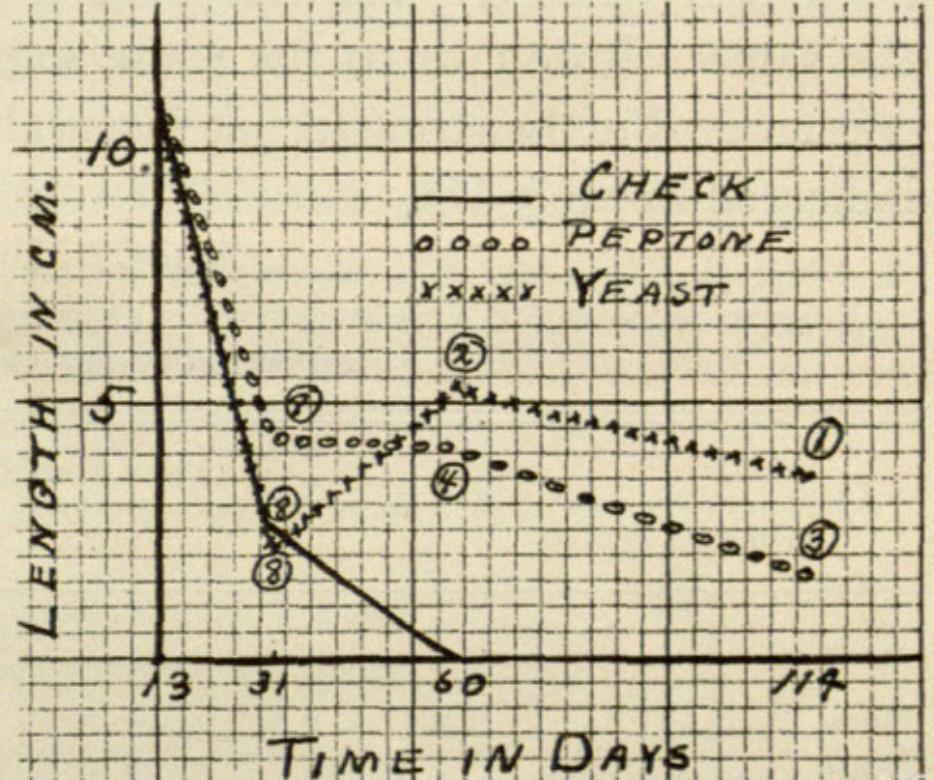

FIG. 3.-Growth in length of root tips of corn in dark for four periods; solutions used were modified Pfeffer's solution plus 2 per cent dextrose (check), and same solution plus approximately 200 ppm yeast or $400 \mathrm{ppm}$ peptone; numbers within the circles represent number of root tips still growing in each period.

of the roots made the check solution more alkaline (table II), raising the $\mathrm{P}_{\mathrm{B}}$ in the first period to $6.3-6.8$, in the second to 5.04 , and barely affecting it in the third period. Both the yeast and the peptone exerted a buffer action, and little change in the reaction was produced in these solutions by the growth of the roots. It was noted that in the Pfeffer's solution containing glucose the change in reaction was roughly proportional to the amount of growth which the roots made. Root tips which grew but little raised the $\mathrm{P}_{\mathrm{H}}$ from 4.5 to $5 . \mathrm{I}$ in the first period; those which made the most growth raised it as high as 6.8. Higher values than this have been obtained. In one case root tips of Silver Mine corn grown for three months in thè modified Pfeffer's solution plus I per cent cane sugar (inverted in sterilizing) changed the $\mathrm{P}_{\mathrm{H}}$ to as high as 8.4.

Experiment 10.--In this experiment the methods followed were as in the first experiment, but two concentrations of peptone were

${ }^{3}$ GillespIE, L. J., Colorimetric determination of $\mathrm{H}$-ion concentration without buffer mixtures. Jour. Amer. Chem. Soc. 42:742-748. 1920. 
used instead of one. The excised primary roots of the germinated grains were grown eleven days in the modified Pfeffer's solution plus 2 per cent glucose. The tips were then cut off and transferred to the same solution, or to the same solution plus autolized yeast or peptone. Further transfers at intervals of two weeks were made, as indicated in table III.

TABLE III

EFFECT OF PEPTONE AND AUTOLIZED YEAST ON CONTINUED GROWTH OF EXCISED CORN ROOT TIPS IN DARK

\begin{tabular}{|c|c|c|c|c|c|}
\hline $\begin{array}{l}\text { Addition to PFEFreR's solu- } \\
\text { tion }+2 \% \text { glucose }\end{array}$ & No. roots tips & $\begin{array}{l}\text { Average origi- } \\
\text { nal length } \\
(\mathrm{cm} .)\end{array}$ & $\begin{array}{l}\text { Average gain } \\
\text { in length } \\
(\mathrm{cm} .)\end{array}$ & $\begin{array}{l}\text { Average no. } \\
\text { secondary } \\
\text { roots }\end{array}$ & $\begin{array}{l}\text { Dry weight } \\
\text { per ro roots } \\
\text { (gm.) }\end{array}$ \\
\hline \multirow{3}{*}{$\begin{array}{l}\text { None } \ldots \ldots \ldots \ldots \ldots \\
\text { None } \ldots \ldots \ldots \ldots \ldots \ldots \\
\text { None } . \ldots \ldots \ldots \ldots \ldots \\
\text { None } \ldots \ldots \ldots \ldots \ldots\end{array}$} & \multicolumn{5}{|c|}{ 1. December 13 -December 24} \\
\hline & $\begin{array}{r}9 \\
13 \\
10 \\
18\end{array}$ & $\begin{array}{l}2.2 \\
\text { I. } 9 \\
\text { I. } 95 \\
\text { I. } 7\end{array}$ & $\begin{array}{l}\text { I } 4.0 \\
\text { I } 4.2 \\
\text { I } 2.9 \\
\text { I } 2.1\end{array}$ & $\begin{array}{l}95 \\
82 \\
98.8 \\
72\end{array}$ & $\begin{array}{c}\cdots \ldots \ldots \\
\ldots \ldots \\
\ldots \ldots\end{array}$ \\
\hline & \multicolumn{5}{|c|}{ 2. December 24-January 8} \\
\hline $\begin{array}{l}\text { None. ................ } \\
200 \mathrm{ppm} \text { autolized yeast. } \\
200 \mathrm{ppm} \text { peptone........ } \\
400 \mathrm{ppm} \text { peptone........ }\end{array}$ & $\begin{array}{r}9 \\
13 \\
9 \\
14\end{array}$ & $\begin{array}{l}2.1 \\
1.9 \\
2.05 \\
2.1\end{array}$ & $\begin{array}{l}2.46 \\
4.8 \\
2.9 \\
3.7\end{array}$ & $\begin{array}{l}\text { I2 } \\
\text { II } \\
\text { I6 } \\
16.7\end{array}$ & $\begin{array}{l}0.0058 \\
0.0087 \\
0.0064 \\
0.0097\end{array}$ \\
\hline \multirow{3}{*}{$\begin{array}{l}\text { None. . . . . } \\
200 \text { ppm autolized yeast. } \\
200 \mathrm{ppm} \text { peptone......... } \\
400 \mathrm{ppm} \text { peptone......... }\end{array}$} & \multicolumn{5}{|c|}{ 3. January 8-January 22} \\
\hline & $\begin{array}{r}7 \\
10 \\
6 \\
12\end{array}$ & $\begin{array}{l}1.8 \\
2.05 \\
\text { I. } 7 \\
2.0\end{array}$ & $\begin{array}{l}0.3 \\
2.9 \\
0.3 \\
1.4\end{array}$ & $\begin{array}{l}\text { I. } 0 \\
4.36 \\
2.0 \\
\text { I. } 6\end{array}$ & $\begin{array}{c}\cdots \cdots \cdots \\
0.003^{2} \\
\ldots \ldots \\
0.0035\end{array}$ \\
\hline & \multicolumn{5}{|c|}{ 4. January $22-$ February 5} \\
\hline $\begin{array}{l}\text { None. . . . . . . . ...... } \\
200 \mathrm{ppm} \text { autolized yeast. } \\
200 \mathrm{ppm} \text { peptone........ } \\
400 \mathrm{ppm} \text { peptone........ }\end{array}$ & $\begin{array}{r}9 \\
6 \\
\text { II }\end{array}$ & $\begin{array}{l}\text { I. } 6 \\
\text { I. } 3 \\
\text { I. } 7\end{array}$ & $\begin{array}{l}0.83 \\
0.50 \\
0.28\end{array}$ & $\begin{array}{l}0.65 \\
0.6 \\
1.0\end{array}$ & $\begin{array}{l}\ldots \ldots \ldots \\
\ldots \ldots \ldots \ldots \\
\ldots \ldots \ldots\end{array}$ \\
\hline
\end{tabular}

Again, toward the end of the second period of growth, the beneficial effect of the peptone and yeast was evident. In this case, however, with the lower winter temperature (ranging around $22^{\circ} \mathrm{C}$. in the dark room used for incubation) the abnormalities so evident in the first experiment were not so numerous, and most of the roots were carried over into the third period. Here the check root tips again stopped growth, while those root tips in the yeast and peptone 
continued to grow. They also grew in the fourth period, and of seven root tips transferred from the solutions containing autolized yeast, one grew from an original length of $1.8 \mathrm{~cm}$. to $2.6 \mathrm{~cm}$. in the fifth period.

It can be noted in table III and in fig. 4 , where the average gains in length of the root tips in this experiment are represented graphically, that there is a continued decrease in the amount of gain in length in each successive period in both the yeast and peptone

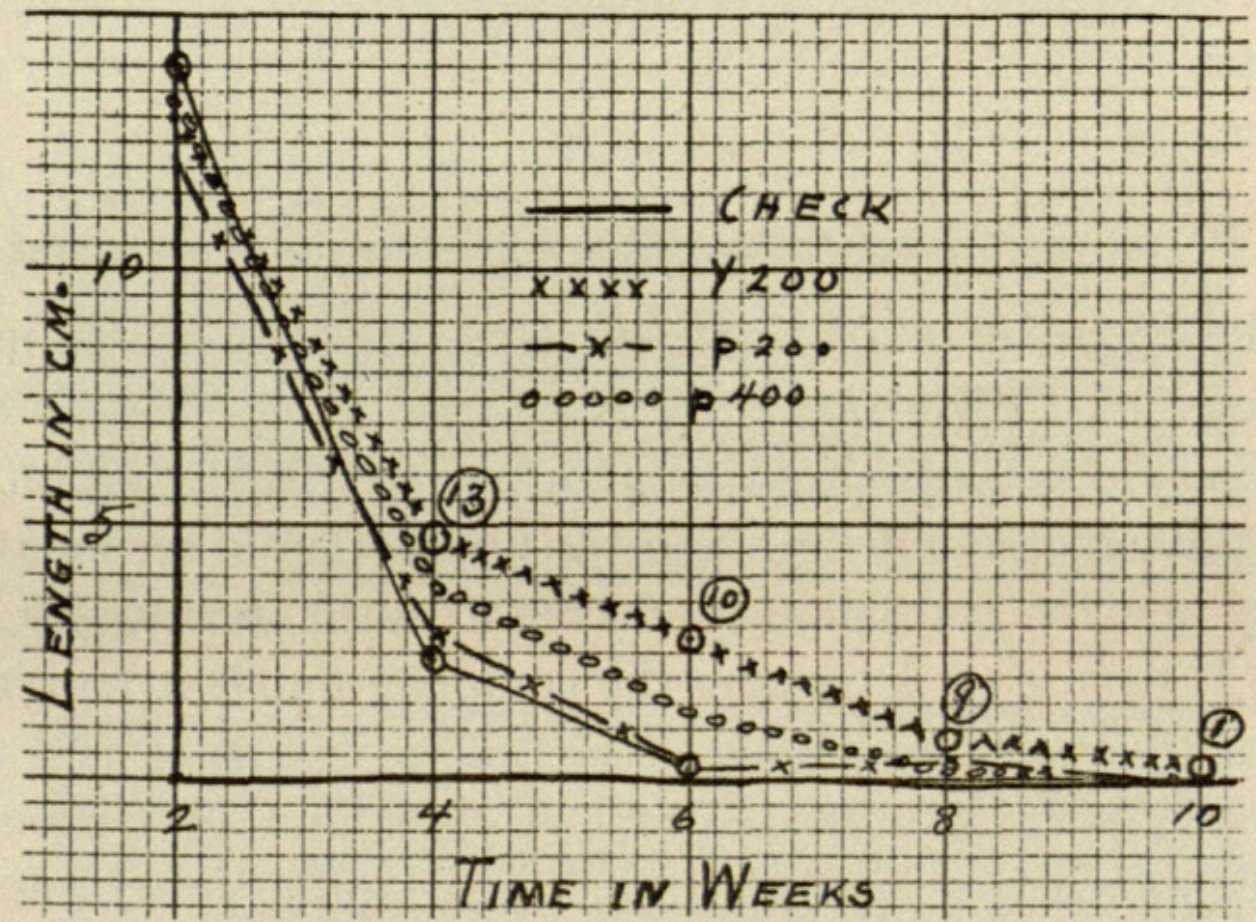

FIG. 4.-Growth in length of excised corn root tips in dark for five periods; solutions used were modified Pfeffer's solution plus 2 per cent glucose (check), same solution plus approximately $200 \mathrm{ppm}$ or $400 \mathrm{ppm}$ peptone (p 200, p 400) or $200 \mathrm{ppm}$ of autolized yeast ( $Y$ 200); numbers within circles represent number of root tips still growing in each period in yeast extract.

solution. The decrease which occurs in the first period is the most marked. The same holds true for the production of secondary roots and for the dry weight produced in each period. The decrease is most marked in the dry weight. The dry matter produced in the second period, even in the presence of yeast or peptone, is only $\frac{1}{11}$ or $\frac{1}{12}$ of that produced in the first period. A consideration of the data of both experiments shows that autolized yeast is superior in its effect to peptone.

An observation made in this experiment as well as generally in others should be recorded. The root tips of some of the excised 
roots in any series always develop abnormally. The root tip becomes clear and glassy, sinks to the bottom of the solution, and almost ceases growth. When this occurs in the early periods of an experiment the secondary roots become unusually long and well developed, frequently attaining a length three or four times that of the secondary roots of an excised root whose tip is developing normally. The appearance of a root whose primary tip became abnormal and whose secondary roots show marked development is shown in fig. 5. A normal root is shown in fig. 6. The latter figure also illustrates the fact noted before that the secondary roots develop from the convex side of the main root.

\section{Effect of different concentrations of autolized yeast}

While autolized yeast and peptone exert a favorable influence on the continued growth of the excised root tips in solution cultures containing glucose and the mineral salts of Pfeffer's solution, nevertheless the increase in length and the production of secondary roots and dry matter continuously decrease, until eventually growth stops. If we are to determine the complete nutrient requirements of a root by the method used, it will be necessary to find a set of conditions in which the excised root tips will grow continuously and produce approximately the same increase in length, number of secondary roots, and dry matter period after period as the root tips are cut off and transferred.

It was hoped that increasing the concentration of the favorable factor already found would accomplish this. Experiments were therefore carried out in which concentrations of autolized yeast varying from ro ppm to $800 \mathrm{ppm}$ were used. The results of these experiments indicated that while $400 \mathrm{ppm}$ were somewhat more favorable than any of the other concentrations used, there was no marked difference in the effects of concentrations as low as ro ppm and as high as $800 \mathrm{ppm}$ so far as the growth in the early periods was concerned. In the later periods, however, the higher concentrations of yeast were more beneficial. Two experiments were performed dealing with this phase. The first extended from February 5 to April I6, the second from April 3 to May I 7, I921. 


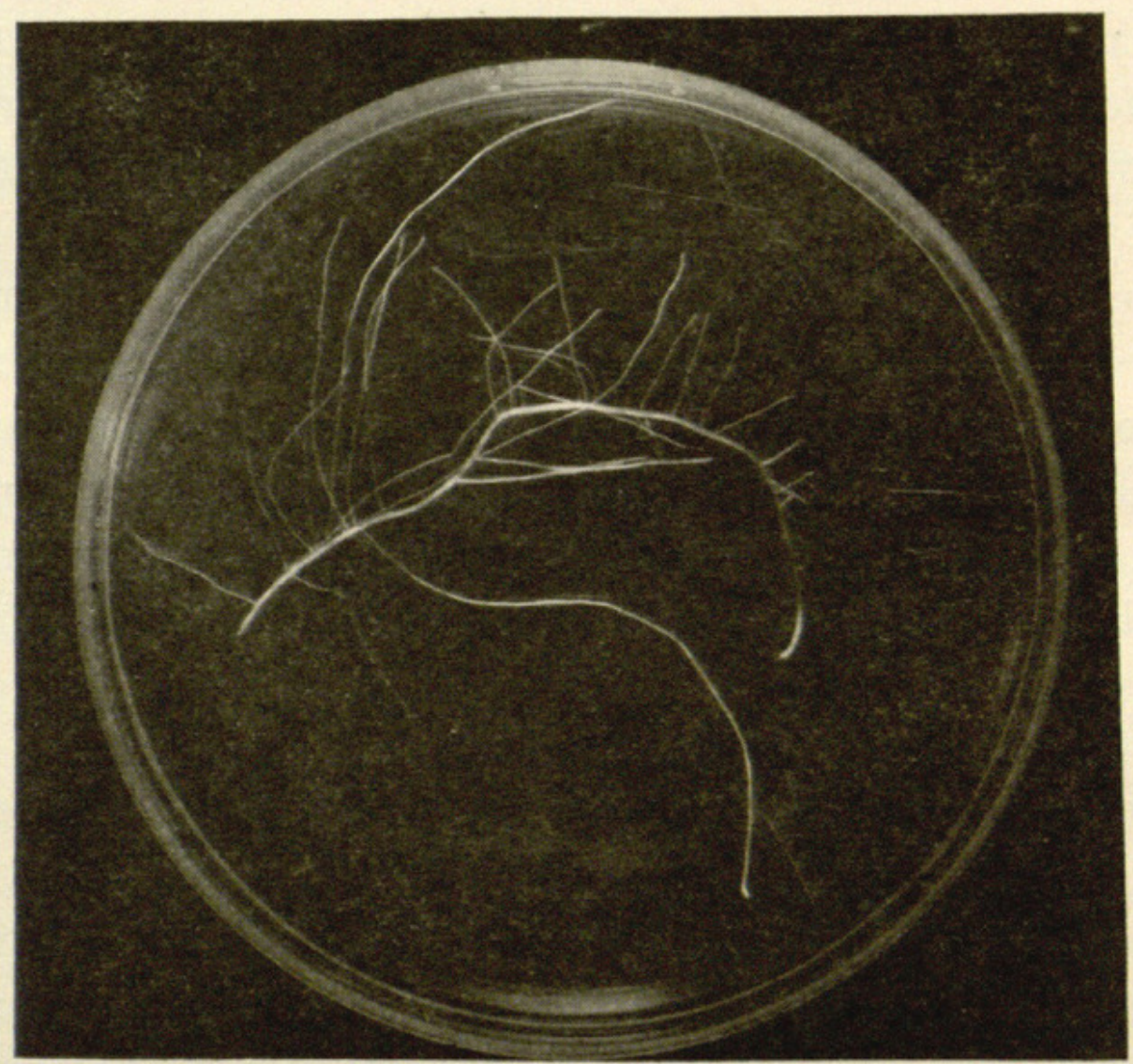

FIG. 5.-Excised corn root whose tip has developed abnormally; note development of secondary roots.

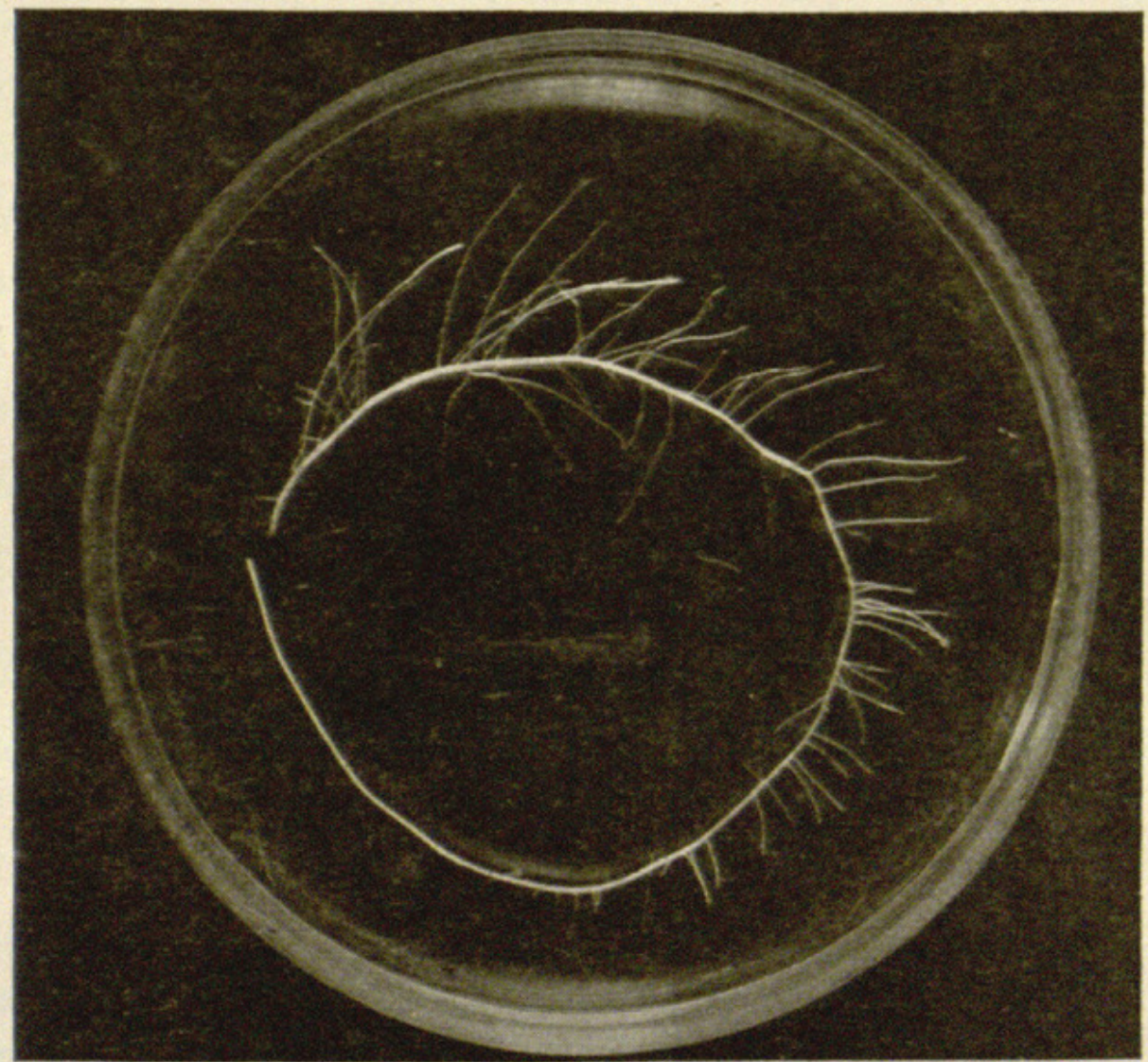

FIG. 6.-Normal excised corn root tip; compare development of secondary roots with those of root in fig. 5 . 
Experiment 12.- The methods used in this experiment were similar to those used in the previous experiments. The root tips were grown at room temperature in the dark in $125 \mathrm{cc}$. Erlenmeyer flasks of Pyrex glass containing $50 \mathrm{cc}$. of solution. The original excised primary roots were grown for the first period in the modified Pfeffer's solution plus 2 per cent glucose, and in the same solution plus $80,200,400$, or $800 \mathrm{ppm}$ of autolized yeast or $200 \mathrm{ppm}$ of Gold Label gelatine, and transferred to fresh solutions of the same composition as in the first period. Further transfers were made as indicated in table IV. In addition, one set of root tips was grown for six weeks in the Pfeffer's solution containing 2 per cent dextrose without transferring, and one set was grown in the same solution plus $400 \mathrm{ppm}$ of autolized yeast for six weeks without severing the tips, and transferring.

The autolized yeast extract used in experiment $\mathrm{I} 2$ was prepared by thoroughly boiling $2 \mathrm{gm}$. of autolized yeast with roo cc. of distilled water, filtering, and making up to the original volume with distilled water. This 2 per cent extract of the autolized yeast actually contained $0.3366 \mathrm{gm}$. of dry matter per $50 \mathrm{cc}$, , of which $0.0525 \mathrm{gm}$. was ash. An extract prepared in the same way was also used in experiment I4. The actual concentration of autolized yeast in the nutrient solutions to which yeast was added was about onethird of the concentrations given, which are based on the weight of the dry yeast as it came from the bottle. Table $\mathrm{V}$ indicates the approximate amounts of dry material, organic matter, and ash added to the culture flasks in the form of the yeast extract.

The data in table IV and the graphic representation of the lengths in fig. 7 show that during the first period the autolized yeast exerted no favorable influence on the growth of the roots. It was not until near the end of the second period that the beneficial effect of the yeast became evident. As was noted earlier, growth in the Pfeffer's solution plus 2 per cent dextrose fell off very markedly in the second period, and stopped in the third. In the presence of autolized yeast, however, the roots grew in the third and fourth periods. The number which could be transferred was decidedly reduced in the fourth period, however, but those which were transferred made some growth in the fifth period, and some of the roots 


\section{TABLE IV}

EFFECT OF DIFFERENT CONCENTRATIONS OF AUTOLIZED YEAST ON CONTINUED GROWTH OF EXCISED CORN ROOTS IN STERILE CULTURE IN DARK

\begin{tabular}{|c|c|c|c|c|c|}
\hline $\begin{array}{l}\text { Addition to PFEFFER's solu- } \\
\text { tion }+2 \% \text { glucose }\end{array}$ & No. root tips & $\begin{array}{l}\text { Average origi- } \\
\text { nal length } \\
(\mathrm{cm} .)\end{array}$ & $\begin{array}{c}\text { Average gain } \\
\text { in length } \\
(\mathrm{cm} .)\end{array}$ & $\begin{array}{l}\text { Average no. } \\
\text { secondary } \\
\text { roots }\end{array}$ & $\begin{array}{l}\text { Dry weight } \\
\text { per ro roots } \\
\text { (gm.) }\end{array}$ \\
\hline \multirow{3}{*}{ 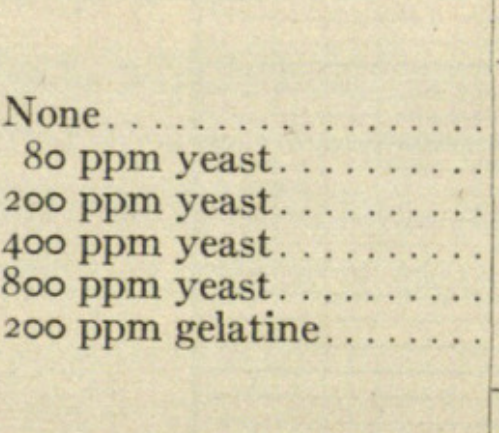 } & \multicolumn{5}{|c|}{ 1. February 5-February 19 } \\
\hline & $\begin{array}{l}\text { I0 } \\
\text { 10 } \\
\text { 10 } \\
\text { 10 } \\
\text { 10 } \\
\text { 10 }\end{array}$ & $\begin{array}{l}\text { I. } 7 \\
\text { I. } 8 \\
\text { I. } 8 \\
\text { I. } 9 \\
\text { I. } 9 \\
\text { I. } 7\end{array}$ & $\begin{array}{l}\text { I2.6 } \\
12.0 \\
11.1 \\
13.0 \\
11.0 \\
10.4\end{array}$ & $\begin{array}{l}67 \\
62 \\
60 \\
72 \\
56 \\
50\end{array}$ & $\begin{array}{l}0.0940 \\
0.0840 \\
0.0730 \\
0.0820 \\
0.0630 \\
0.0624\end{array}$ \\
\hline & \multicolumn{5}{|c|}{ 2. February 19-March 5} \\
\hline 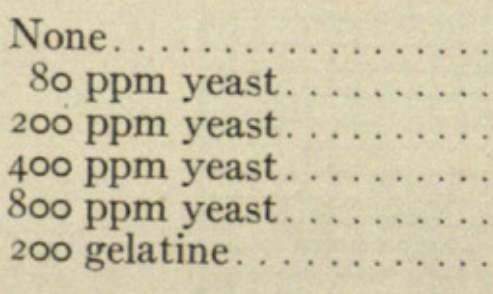 & $\begin{array}{l}9 \\
\text { 10 } \\
\text { 10 } \\
\text { 10 } \\
\text { 10 } \\
\text { 10 }\end{array}$ & $\begin{array}{l}2.3 \\
1.9 \\
2.16 \\
2.0 \\
2.1 \\
\text { I. } 85\end{array}$ & $\begin{array}{l}3 \cdot 0 \\
5 \cdot 97 \\
5 \cdot 71 \\
5 \cdot 4 \\
5 \cdot 5 \\
2 \cdot 12\end{array}$ & $\begin{array}{r}9.6 \\
6.1 \\
14.0 \\
13.2 \\
9.0 \\
3.7\end{array}$ & $\begin{array}{l}0.0051 \\
0.0056 \\
0.0116 \\
0.0096 \\
0.0104 \\
0.0044\end{array}$ \\
\hline & \multicolumn{5}{|c|}{ 3. March 5-March 19} \\
\hline 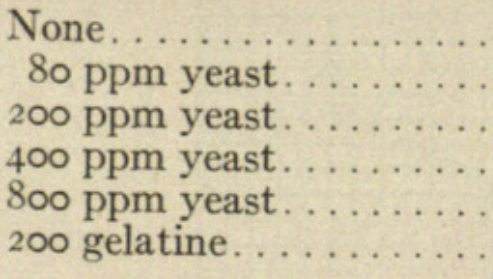 & $\begin{array}{l}9 \\
8 \\
8 \\
8 \\
6 \\
7\end{array}$ & $\begin{array}{l}\text { I. } 9 \\
\text { I. } 8 \\
\text { I. } 7 \\
\text { I. } 9 \\
\text { I. } 6 \\
\text { I. } 5\end{array}$ & $\begin{array}{l}0.2 \\
4.0 \\
4.2 \\
3.6 \\
4.4 \\
0.1\end{array}$ & $\begin{array}{r}2.9 \\
6.5 \\
7.4 \\
9.6 \\
10.7 \\
0\end{array}$ & $\begin{array}{r}0.0015 \\
0.0035 \\
0.0043 \\
0.0055 \\
0.0110 \\
\end{array}$ \\
\hline
\end{tabular}

4. March r9-April 2

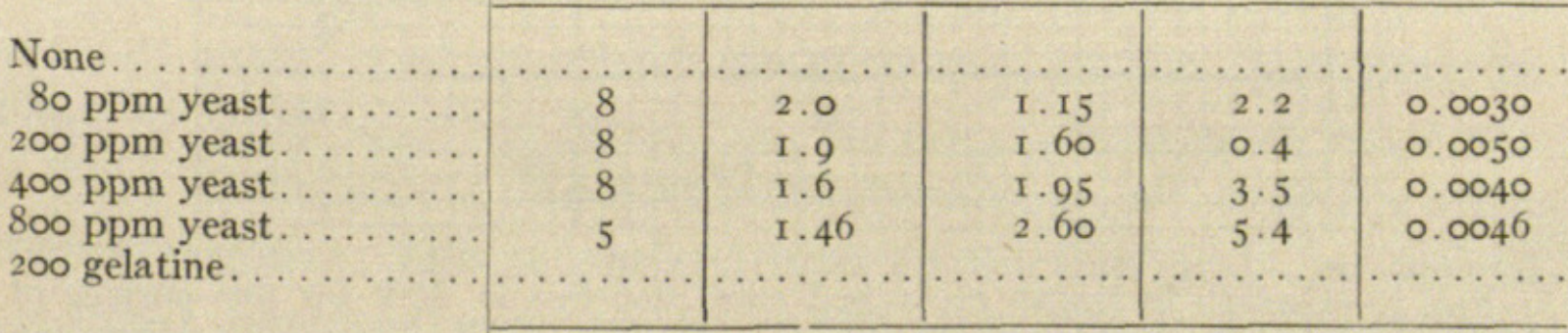

5. April 2-April I6

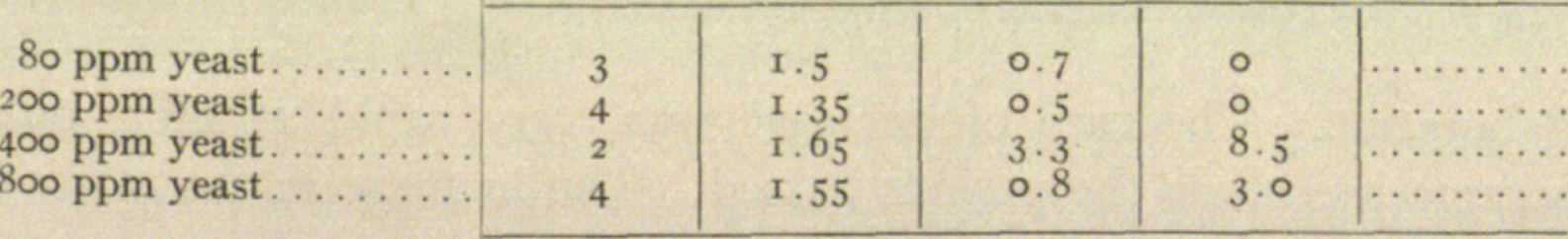

February 5-March 19

\begin{tabular}{lr|l|l|l|l} 
None............... & 9 & 2.0 & 20.4 & 84 & 0.0898 \\
400 ppm yeast......... & r 3 & 1.93 & 20.57 & 97 & 0.0635 \\
\hline
\end{tabular}


grew in the sixth period. All the roots still growing were accidentally lost in the sixth period.

An examination of the data in table $\mathrm{V}$ and the curves in fig. 7 shows that none of the yeast concentrations prevented the gradual decrease in length gain, secondary root production, and dry matter

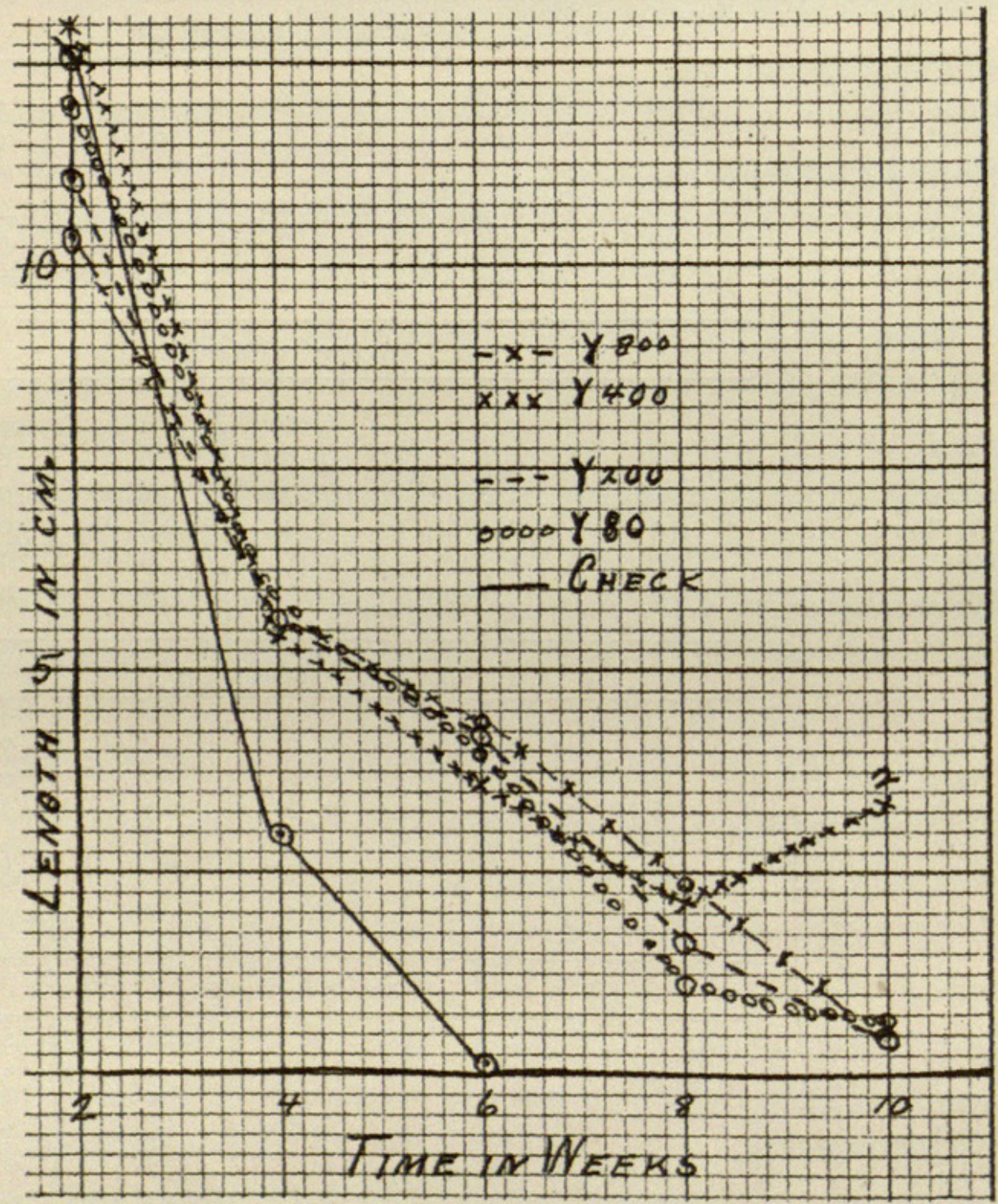

Fig. 7. - Growth in length of excised corn root tips in dark for five periods of transfers; solutions used were Pfeffer's solution plus 2 per cent glucose (check), and same solution plus $80,200,400$, or 800 ppm autolized yeast.

elaboration. The rate of decrease was very rapid at first, but became less so as the periods passed. The increase in the rate of growth in $400 \mathrm{ppm}$ of autolized yeast in the fifth period is apparent only. It is due to the fact that two roots only out of the eight of the fourth period grew in the fifth period. Their growth was excellent throughout the experiment, but decreased continuously. The 
increases in length for one of these roots, no. 32 , for the five periods were as follows: Ir.2, 6.5, 4.9, 4.5, and I. $3 \mathrm{~cm}$., and the secondary root production was $58,12,3,4$, and o. For the other, no. 39,

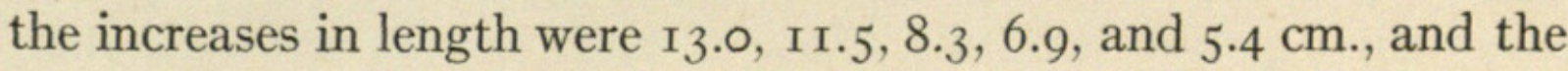
secondary root production was $82,51,25,16$, and I 7 . These figures show a continuous decrease in length. They also emphasize the fact, which has been observed continuously in this work, that the root tips act consistently as individuals period after period. A root tip which develops well in the first and second periods usually continues to show a superior growth in the later periods.

\section{TABLE V}

APPROXIMATE ACTUAL MATERIAL, ASH, OR ORGANIC MATERIAL

ADDED IN AUTOLIZED YEAST EXTRACT TO CULTURE SOLUTIONS IN EXPERIMENTS I 2 AND I4

\begin{tabular}{|c|c|c|c|c|}
\hline $\begin{array}{c}\text { Concentrations of } \\
\text { autolized yeast } \\
\text { in culture solutions } \\
\text { expressed as } \\
\text { bottle-dry yeast } \\
\text { (ppm) }\end{array}$ & $\begin{array}{l}\text { Total dry } \\
\text { matter (ppm) }\end{array}$ & Ash (ppm) & $\begin{array}{l}\text { Organic } \\
\text { (ppm) }\end{array}$ & $\begin{array}{c}\text { Total dry } \\
\text { matter added } \\
\text { per } 50 \text { cc. of } \\
\text { culture } \\
\text { medium (gm.) }\end{array}$ \\
\hline 10........... & $3 \cdot 7$ & 0.5 & 3.0 & 0.00016 \\
\hline $40 \ldots \ldots \ldots$ & $13 \cdot 5$ & 2.0 & II. 5 & 0.00065 \\
\hline $80 \ldots \ldots$ & 27.0 & $4 \cdot 0$ & 23.0 & 0.0013 \\
\hline $200 \ldots \ldots$ & 67.0 & I0. 5 & $5^{6} \cdot 5$ & 0.0032 \\
\hline $400 \ldots \ldots$ & 134.0 & 21.0 & II 3.0 & 0.0067 \\
\hline $800 \ldots$. & 268.0 & 42.0 & 226.0 & 0.0134 \\
\hline
\end{tabular}

The difference in the effect of the various concentrations of yeast was not great, and appeared most sharply in the later periods. Thus, so far as length is concerned, the gain in $80 \mathrm{ppm}$ of yeast was as great in the second and in the third period as in any of the other concentrations. The secondary root production and dry weight produced, however, were greater in the higher yeast concentrations even in the second period. It was not until the fifth period that $200 \mathrm{ppm}$ of yeast showed its inferiority to $400 \mathrm{ppm} ; 800 \mathrm{ppm}$ of yeast apparently was somewhat too concentrated. The addition of $200 \mathrm{ppm}$ of a colloidal material like gelatine to the culture solution did not favorably affect the development of the roots. It should be noted that root hairs were found on the root tips in the gelatine solution at the end of the third period. Excised roots which did not have their root tips severed and transferred at intervals 
(table VI) made just as much growth in length in a period of six weeks in Pfeffer's solution plus 2 per cent glucose as in Pfeffer's solution plus 2 per cent glucose and $400 \mathrm{ppm}$ of autolized yeast.

\section{TABLE VI}

GROWTH OF EXCISED CORN ROOTS IN STERILE NUTRIENT SOLUTIONS IN DARK; IN ONE CASE ORIGINAL EXCISED ROOT TIPS NOT TRANSFERRED; IN OTHER TIPS CUT OFF AND TRANSFERRED TO FRESH NUTRIENT SOLUTIONS AT INTERVALS OF TWO WEEKS; COMPILED FROM DATA IN TABLE IV

\begin{tabular}{|c|c|c|c|c|c|c|}
\hline Addition to PrEFrer's solution & Transfers & No. roots & $\begin{array}{l}\text { Average } \\
\text { original } \\
\text { length } \\
\text { (cm.) }\end{array}$ & $\begin{array}{c}\text { Total aver- } \\
\text { age gain } \\
\text { in length } \\
\text { (cm.) }\end{array}$ & $\begin{array}{l}\text { Average } \\
\text { no. second- } \\
\text { ary roots }\end{array}$ & $\begin{array}{l}\text { Dry weight } \\
\text { per ro } \\
\text { roots (gm.) }\end{array}$ \\
\hline \multirow{3}{*}{$\begin{array}{l}\text { None......................... } \\
400 \text { ppm autolized yeast. }\end{array}$} & \multicolumn{6}{|c|}{ February 5 -March 19} \\
\hline & $\begin{array}{l}\text { None } \\
\ldots \ldots\end{array}$ & $\begin{array}{r}9 \\
13\end{array}$ & $\begin{array}{l}2.0 \\
\text { I. } 93\end{array}$ & $\begin{array}{l}20.4 \\
20.57\end{array}$ & $\begin{array}{l}84 \\
97\end{array}$ & $\begin{array}{l}0.0898 \\
0.0635\end{array}$ \\
\hline & \multicolumn{6}{|c|}{ February 5-March 19} \\
\hline $\begin{array}{l}\text { None..................... } \\
400 \text { ppm autolized yeast... }\end{array}$ & 3 & $\begin{array}{l}9-10 \\
8-9\end{array}$ & $\begin{array}{l}\text { I. } 7 \\
\text { I. } 9\end{array}$ & $\begin{array}{l}15.8 \\
22.0\end{array}$ & $\begin{array}{l}79 \cdot 5 \\
94 \cdot 8\end{array}$ & $\begin{array}{l}0.1006 \\
0.0971\end{array}$ \\
\hline
\end{tabular}

\section{TABLE VII}

EFFECTS OF IO, 40, AND 8O PPM OF AUTOLIZED YEAST EXTRACT ON GROWTH OF EXCISED CORN ROOT TIPS IN STERILE NUTRIENT SOLUTIONS IN DARK

\begin{tabular}{|c|c|c|c|c|c|}
\hline $\begin{array}{l}\text { Addition to PFEFFER's solu- } \\
\text { tion }+2 \% \text { glucose }\end{array}$ & No. roots & $\begin{array}{l}\text { Average origi- } \\
\text { nal length } \\
\text { (cm.) }\end{array}$ & $\begin{array}{l}\text { Average gain } \\
\text { in length } \\
(\mathrm{cm} .)\end{array}$ & $\begin{array}{l}\text { Average no. } \\
\text { secondary } \\
\text { roots }\end{array}$ & $\begin{array}{l}\text { Dry weight } \\
\text { per ro roots } \\
\text { (gm.) }\end{array}$ \\
\hline & \multicolumn{5}{|c|}{ r. April 3-April r7 } \\
\hline 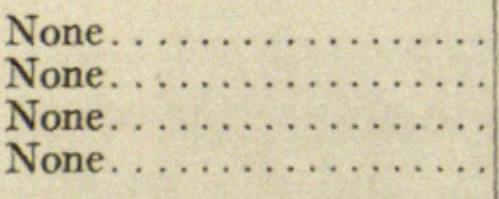 & $\begin{array}{l}10 \\
10 \\
10 \\
10\end{array}$ & $\begin{array}{l}\text { I. } 57 \\
\text { I. } 68 \\
\text { I. } 75 \\
\text { I. } 68\end{array}$ & $\begin{array}{l}\text { II. } 51 \\
\text { II. I } \\
\text { II. } 25 \\
\text { I } 2.22\end{array}$ & $\begin{array}{l}65 \\
64 \\
65 \\
71\end{array}$ & $\begin{array}{c}0.1054 \\
\cdots \cdots \\
0.0826\end{array}$ \\
\hline None................ & \multicolumn{5}{|c|}{ 2. April ${ }_{17}-\mathrm{April}_{30}$} \\
\hline 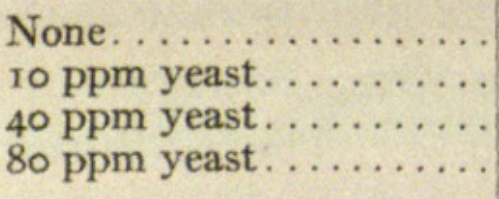 & $\begin{array}{l}8 \\
5 \\
3 \\
3\end{array}$ & $\begin{array}{l}\text { I. } 8 \\
\text { I. } 96 \\
\text { I. } 9 \\
2.0\end{array}$ & $\begin{array}{l}\text { I. } 25 \\
3.48 \\
2.5 \\
2.8\end{array}$ & $\begin{array}{l}7.5 \\
9.0 \\
6.0 \\
2.0\end{array}$ & $\begin{array}{c}0.0027 \\
0.0047 \\
\cdots \\
\cdots\end{array}$ \\
\hline & \multicolumn{5}{|c|}{ 3. April $30-\mathrm{May}_{4}$} \\
\hline 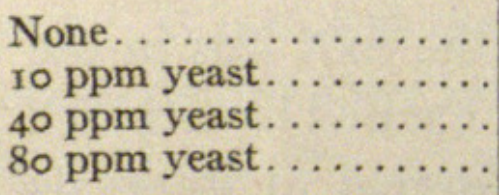 & $\begin{array}{l}8 \\
5 \\
2 \\
2\end{array}$ & $\begin{array}{l}\text { I. } 4 \\
\text { I. } 8 \\
\text { I. } 8 \\
\text { I. } 6\end{array}$ & $\begin{array}{l}\text { O. I } 3 \\
\text { I. } 5 \\
\text { I. } 5 \\
\text { I. I }\end{array}$ & $\begin{array}{l}0 \\
1.2 \\
0 \\
0\end{array}$ & $\begin{array}{l}\ldots \ldots \ldots \\
\ldots \ldots \cdots \\
\cdots \cdots \cdots \\
\cdots \cdots\end{array}$ \\
\hline
\end{tabular}


The secondary root production in the autolized yeast culture was somewhat greater and dry matter somewhat less in this case.

If we compare the growth of roots which had their tips severed and were transferred twice to fresh solutions during a six weeks' period with those which grew continuously undisturbed in the solution, we find (table VI) that in Pfeffer's solution plus 2 per cent glucose the total increase in length and production of secondary roots when the tips were severed and transferred was less than when they were left undisturbed; the dry matter was greater. When yeast was present the length and secondary root production were not affected by the transfers; the dry weight was greater.

The original $\mathrm{P}_{\mathrm{н}}$ of the Pfeffer's solution plus 2 per cent glucose was 4.5. The roots which grew for six weeks without transfer changed the reaction to $P_{\text {н }}$ 6.3. The original reaction of the Pfeffer's solution plus 2 per cent glucose and $400 \mathrm{ppm}$ of yeast was $\mathrm{P}_{\text {в }} 5.2$. The roots which grew for six weeks without transfer changed the reaction to a $\mathrm{P}_{\mathrm{H}}$ of 6.24 .

Experiment I 4.-The methods and general conditions were the same in this experiment as in experiment $\mathrm{I} 2$. In this case, however, concentrations of yeast of Io, 40 , and $80 \mathrm{ppm}$ were used. The root tips were grown for the first period with no addition to the nutrient solution, the yeast being added in the second period. Unfortunately one of the flasks containing the concentrated yeast extract was contaminated with bacteria, and most of the cultures were lost in the second period due

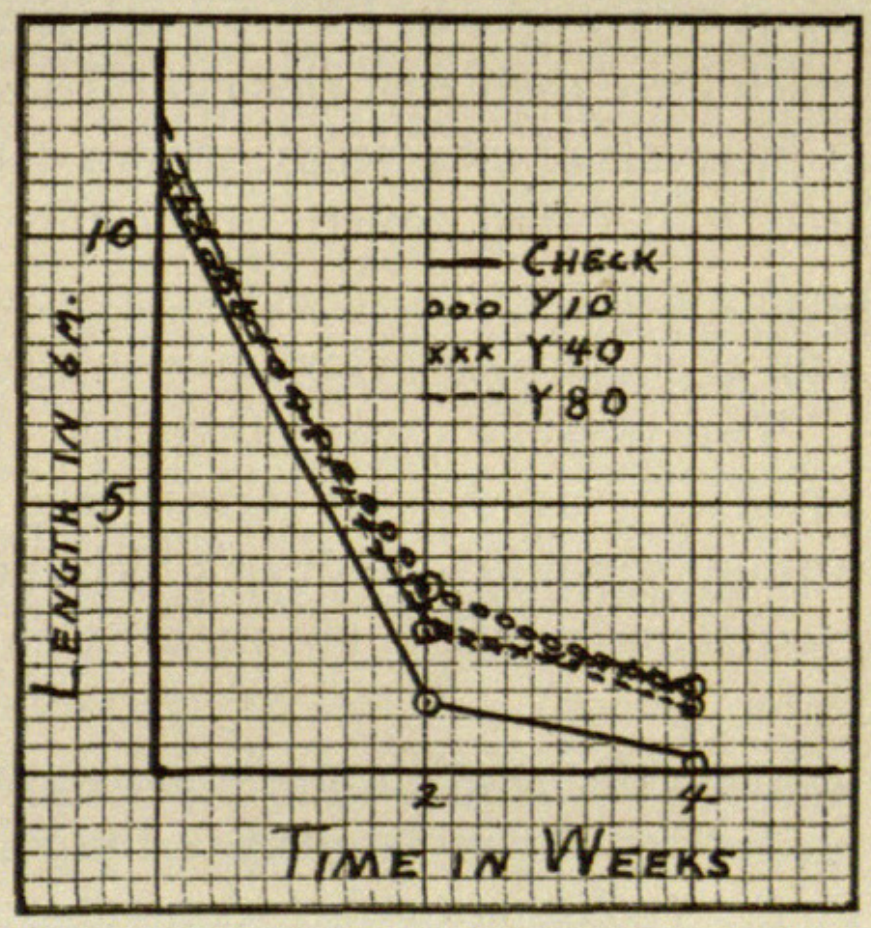

FIG. 8.-Growth in length of excised corn root tips in dark for three periods of transfers; solutions used were Pfeffer's solution plus 2 per cent glucose, and same solution plus 10, 40 , or $80 \mathrm{ppm}$ of autolized yeast. to the contamination, leaving but two root tips in each of the concentrations, $40 \mathrm{ppm}$ and $80 \mathrm{ppm}$. From the data in table VII and the graphic representations in fig. 8 it can be noted that the 
growth in ro ppm of autolized yeast in the second period compares very favorably with that in $40 \mathrm{ppm}$ or $80 \mathrm{ppm}$ of yeast in the same experiment. In the third period the development in the solution containing ro $\mathrm{ppm}$ of autolized yeast was better than in either 40 or $80 \mathrm{ppm}$ of yeast. If, however, we compare it with the previous experiment in which a larger number of root tips were grown in $80 \mathrm{ppm}$ yeast, we can see that the development was considerably less in ro ppm than in $80 \mathrm{ppm}$ of yeast. This substantiates the general expression of the effect of autolized yeast in these experiments, namely, that in the first period it has no beneficial effect, in the second period there is little difference between the effects of $10,40,80,200,400$, and $800 \mathrm{ppm}$; but the later the period the more evident does the beneficial action of the higher concentrations appear.

\section{Discussion}

While excised corn root tips which are grown in the dark for about two weeks in Pfeffer's solution plus 2 per cent glucose, and which have their root tips cut off and transferred to fresh solutions at intervals of two weeks, show a continued decrease in the rate of growth and stop growth in the third period, the addition of small amounts of peptone or autolized yeast permits them to grow for as long as six periods before growth ceases.

Two possible explanations for the action of the peptone and autolized yeast suggest themselves: (I) the autolized yeast or the peptone supplies something which the root requires for its continued growth and which is not included in the salts of Pfeffer's solution, water, glucose, and free oxygen; (2) the autolized yeast or peptone balances the solution, performing a function which could be accomplished by a readjustment of the relative quantities of the salts of Pfeffer's solution or their equivalents, of water, of glucose, and of free oxygen. A definite decision between these two possibilities cannot be made from the data at hand. The majority of the results reported in this paper, however, would seem to be explained best on the assumption that the mineral salts of Pfeffer's solution, glucose, free oxygen, and water are insufficient for the continued growth of the root cells of corn, and that this deficiency can partially be supplied by autolized yeast or peptone. 
That the effect of the peptone or autolized yeast is not protective is indicated by the fact that a colloidal material like gelatine is not beneficial, and by the fact that the beneficial action of the yeast does not appear in the first period of two weeks, or even in six weeks when the excised roots do not have their tips cut off and transferred to fresh solutions. The assumption, however, that the seedling root contains some substance or substances derived from the grain which are not contained in the basic nutrient solution and which are supplied by the peptone or autolized yeast would explain: (I) That root tips transferred show less total growth than those not transferred. The hypothetical materials are fractionated in the transfers, and the transferred root is limited in the second and third periods by a deficiency of these materials, which can partially be supplied by the peptone and autolized yeast. (2) That in the presence of autolized yeast root tips transferred show as much growth as those not transferred. The hypothetical substances fractionated in the transfers are supplied by the autolized yeast. (3) The fact that with the cessation of growth of the root tip of an excised root there occurs an excessive development of secondary roots. The hypothetical materials which are not used in the growth of the main root tip are utilized for growth by the meristematic tissue of the secondary roots.

Whatever the cause of the beneficial action of the autolized yeast, ${ }^{4}$ its effect is limited in some way, as is evidenced by the fact that the various concentrations of yeast produce no correspondingly increased benefits, and the Pfeffer's solution containing peptone or autolized yeast and glucose will not permit continued growth.

\section{Summary}

I. Corn roots attached to the grain grow much more rapidly under sterile conditions in the dark in Pfeffer's solution plus 2 per cent glucose than do root tips detached from the grain.

${ }^{4}$ Lack of space precludes a summary at this time of the voluminous literature dealing with this general problem. Reference should be made to the publications of Sachs, Haberlandt, Hannig, Bottomley, Weber, Bachman, Loeb, Mockeridge, Fulmer, Nelson and Sherwood, Williams, and others who have dealt previously with the problem of the necessity of accessory food substances for plant growth, or who have attempted to cultivate single cells or isolated parts of higher plants. Some of the more recent papers on this subject not cited in the earlier publication by the writer are given at the end of this paper. A review of the subject indicated is planned for a later publication. 
2. When excised root tips of corn are grown under sterile conditions for about two weeks in the dark in Pfeffer's solution plus 2 per cent glucose, and their root tips are severed and transferred to fresh solutions at intervals: (a) growth stops in the third period; (b) the addition of peptone or autolized yeast permits the root tips to grow for $4^{-6}$ periods; $(c)$ a concentration of $200 \mathrm{ppm}$ of gelatine, roo ppm of creatinine, $79 \mathrm{ppm}$ of glycocoll, $50 \mathrm{ppm}$ of asparagin, or the corn embryo extract used show no beneficial effect; $(d)$ in Pfeffer's solution lacking nitrates and containing 2 per cent glucose a little less total growth is made than in Pfeffer's solution containing nitrates and 2 per cent glucose; (e) approximately $400 \mathrm{ppm}$ of peptone is more efficient than $200 \mathrm{ppm} ;(f)$ autolized yeast is more beneficial than peptone; $(g)$ the beneficial effect of the autolized yeast does not appear in the first period of growth; $(h)$ concentrations of $10,40,80,200,400$, and $800 \mathrm{ppm}$ of autolized yeast (equivalent in dry matter to about one-third the concentrations given) show no marked difference in their beneficial effect, especially in the early periods; ( $i$ ) the higher concentrations of yeast evidence a somewhat greater beneficial effect in the later periods than the lower concentrations.

3. When the total growth of excised corn root tips whose tips are cut off and transferred twice in a six weeks' period is compared with that of root tips left undisturbed, then $(a)$ in Pfeffer's solution plus 2 per cent glucose in the dark the total growth in length and production of secondary roots are less, the dry weight is greater; $(b)$ in Pfeffer's solution plus 2 per cent glucose and $400 \mathrm{ppm}$ of autolized yeast there is no difference in the growth in length or secondary root production; the dry weight is greater.

4. When the growth of excised root tips left undisturbed for six weeks in Pfeffer's solution plus 2 per cent glucose is compared with the growth in the same solution to which $400 \mathrm{ppm}$ of autolized yeast is added, there is no difference in total length. The secondary root production is somewhat less and dry weight somewhat greater.

5. Excised corn root tips act as individuals.

6. The growth of the secondary roots of an excised root is much greater when the primary root tip stops growth than when it continues to grow normally. 


\section{LITERATURE CITED}

I. BACHMAN, FredA W., Vitamine requirements of certain yeasts. Jour. Biol. Chem. 39:235-258. I919.

2. Botтomley, W. B., The significance of certain food substances for plant growth. Ann. Botany 28:531-539. I9I4.

3. Fulmer, E. I., Nelson, V. E., and Sherwood, F. F., The nutritional requirements of yeast. I. The rôle of vitamines in the growth of yeast; II. The effect of the composition of the medium on the growth of yeast. Jour. Amer. Chem. Soc. 43:186-199. I92I.

4. Gillespie, L. J., Colorimetric determination of hydrogen-ion concentration without buffer mixtures. Jour. Amer. Chem. Soc. 42:742-748. I920.

5. LOEB, J., Rules and mechanism of inhibition and correlation in the regeneration of Bryophyllum calycinum. Bот. GAz. 60:249-276. I9I8.

6. MacDonald, M. B., and McCollum, E. V., The cultivation of yeast in solutions of purified nutrients. Jour. Biol. Chem. 45:307-3Ir. I92I.

7. Mockeridge, F. A., XXXVII. The occurrence and nature of plant growth-promoting substances in various manurial composts. Biochem. Jour. 14:432-450. 1920.

8. Robbins, W. J., The cultivation of excised root tips and stem tips under sterile conditions. Bот. GAz. 73:376-39o. 1922 .

9. Williams, R. J., Vitamines and yeast growth. Jour. Biol. Chem. 46: II3-II8. I92I.

ro. Weber, F., Hormone in Pflanzenreich. Naturwiss. Wochenschr. 35 : 24I-253. 1920 . 


\section{$2 \mathrm{BHL}$ Biodiversity Heritage Library}

Robbins, William J. 1922. "Effect of Autolized Yeast and Peptone on Growth of Excised Corn Root Tips in the Dark." Botanical gazette 74(1), 59-79. https://doi.org/10.1086/333055.

View This Item Online: https://www.biodiversitylibrary.org/item/109581

DOI: https://doi.org/10.1086/333055

Permalink: https://www.biodiversitylibrary.org/partpdf/224384

\section{Holding Institution}

Missouri Botanical Garden, Peter H. Raven Library

\section{Sponsored by}

Missouri Botanical Garden

\section{Copyright \& Reuse}

Copyright Status: Public domain. The BHL considers that this work is no longer under copyright protection.

This document was created from content at the Biodiversity Heritage Library, the world's largest open access digital library for biodiversity literature and archives. Visit BHL at https://www.biodiversitylibrary.org. 